\title{
Seasonal variations in temperature sensitivity of soil respiration in a larch forest in the Northern Daxing'an Mountains in Northeast China
}

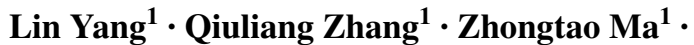 \\ Huijun Jin ${ }^{2,3} \cdot$ Xiaoli Chang ${ }^{2}$ Sergey S. Marchenko ${ }^{4}$. \\ Valentin V. Spektor ${ }^{5}$
}

Received: 21 June 2020 / Accepted: 25 January 2021 / Published online: 11 May 2021

(C) The Author(s) 2021

\begin{abstract}
Temperature sensitivity of respiration of forest soils is important for its responses to climate warming and for the accurate assessment of soil carbon budget. The sensitivity of temperature $\left(T_{i}\right)$ to soil respiration rate $\left(R_{s}\right)$, and $Q_{10}$ defined by $\mathrm{e}^{10(\ln R s-\ln a) / T i}$ has been used extensively for indicating the sensitivity of soil respiration. The soil respiration under a larch (Larix gmelinii) forest in the northern Daxing' an Mountains, Northeast China was observed in situ from April to September, 2019 using the dynamic chamber method. Air temperatures $\left(T_{\text {air }}\right)$, soil surface temperatures $\left(T_{0 \mathrm{~cm}}\right)$, soil temperatures at depths of 5 and $10 \mathrm{~cm}\left(T_{5 \mathrm{~cm}}\right.$ and $T_{10 \mathrm{~cm}}$, respectively), and soil-surface water vapor concentrations were monitored at the same time. The results show a significant monthly variability in soil respiration rate in the growing season (April-September). The $Q_{10}$
\end{abstract}

Project funding: This work is financially supported by the CFERN \& the Funds of the Beijing Techno Solutions Award on Excellence in Academic Achievements and the National Key Research and Development Program of China (2017YFC0504003).

The online version is available at http://www.springerlink.com

Corresponding editor: Yu Lei

Qiuliang Zhang

Zqlemail@imau.edu.cn

1 College of Forestry and Da Xing' anling Forest Ecosystem Research Station of Inner Mongolia Autonomous Region, Inner Mongolia Agricultural University, Hohhot 010019, People's Republic of China

2 Research-Station of Permafrost Geo-Environment, Ministry of Education, Institute of Cold Regions Science and Engineering and School of Civil Engineering, Northeast Forestry University, Harbin 150040, People's Republic of China at the surface and at depths of 5 and $10 \mathrm{~cm}$ was estimated at 5.6, 6.3, and 7.2, respectively. The $Q_{10 @ 10 \mathrm{~cm}}$ over the period of surface soil thawing $\left(Q_{10 @ 10 \mathrm{~cm} \text {, thaw }}=36.89\right)$ were significantly higher than that of the growing season $\left(Q_{10 @ 10 \mathrm{~cm} \text {, growth }}=3.82\right)$. Furthermore, the $R_{s}$ in the early stage of near-surface soil thawing and in the middle of the growing season is more sensitive to changes in soil temperatures. Soil temperature is thus the dominant factor for season variations in soil respiration, but rainfall is the main controller for short-term fluctuations in respiration. Thus, the higher sensitivity of soil respiration to temperature $\left(Q_{10}\right)$ is found in the middle part of the growing season. The monthly and seasonal $Q_{10}$ values better reflect the responsiveness of soil respiration to changes in hydrometeorology and ground freeze-thaw processes. This study may help assess the stability of the soil carbon pool and strength of carbon fluxes in the larch forested permafrost regions in the northern Daxing' an Mountains.

Keywords Soil respiration - Dynamic chamber method . Ground thawing $\cdot$ Major growth period $\cdot$ Soil temperature

3 State Key Laboratory of Frozen Soils Engineering, Northwest Institute of Eco-Environment and Resources, Chinese Academy of Sciences, Lanzhou 730000, People's Republic of China

4 Geophysical Institute, University of Alaska Fairbanks, Fairbanks, AK 99775, USA

5 Laboratory of General Geocryology, Melnikov Permafrost Institute, Siberia Branch, Russian Academy of Sciences, Yakutsk, Russia 677010 


\section{Introduction}

Temperature and moisture content are key to seasonal variations in soil respiration (Paustian et al. 2016). To facilitate relevant studies, a $Q_{10}$ has been defined as the degree of temperature sensitivity of soil respiration. The assessment of $Q_{10}$ has been widely used as an important parameter in biogeochemical models (Raich and Tufekcioglu 2000). However, $Q_{10}$ is spatiotemporally heterogeneous, and it exhibits not only significant seasonal variations, but also those variations with latitude and vegetation types (Powlson et al. 2011). Current estimates of carbon emissions from terrestrial ecosystems and the direct impacts of climate change are thus directly influenced and/or predicted by $Q_{10}$ values (Schlesinger and Andrews 2000). Furthermore, $Q_{10}$ largely determines the feedback relationship between climate change and carbon cycling (Pokharel et al. 2018). Therefore, under a warming climate, it is important to understand $Q_{10}$ changes and their influencing factors in order to more accurately simulate and predict the key parameters of carbon cycles and processes and to clarify the relationship between soil respiration and its temperature sensitivity.

$Q_{10}$ displays marked daily, monthly, seasonal and interannual variations ( $\mathrm{Li}$ et al. 2020). According to its influencing factors, intrinsic and apparent $Q_{10}$ values are divided (Yan et al. 2019). The former is the intrinsic sensitivity of soil respiration to soil temperature without taking into account all external factors; the latter (apparent sensitivity) is the sensitivity of soil respiration to soil temperature under the natural state (Chen and Tian 2005). At present, it is difficult to integrate temperature into the intrinsic or apparent $Q_{10}$ values (Zhou et al. 2015). Therefore, most of the observed values are the apparent $Q_{10}$. Daily variations in soil moisture are insignificant, i.e., the growth of plant roots is almost invisible and the microbial population and community remain almost unchanged (Qin et al. 2015). However, at seasonal and interannual time-scales, $Q_{10}$ values well reflect these variations, including not only the responses of soil respiration to changes in soil temperature, but also to changes in soil water content, root biomass, surficial litter input, soil microbial population, and others (Qi et al. 2014). These complex response processes increase the uncertainty in the estimation of $Q_{10}$ (Schindlbacher et al. 2014). Therefore, understanding the changes in $Q_{10}$ is basic for correctly estimating the feedbacks between climate change and the carbon cycle (Mahecha et al. 2010; Liu et al. 2020).

In several studies, $Q_{10}$ values have varied substantially with latitude and ecosystem types (Yan et al. 2019). Comprehensive analysis indicates a high sensitivity of soil respiration rates $\left(R_{s}\right)$ to temperature increases in cold environments, and the fitting between $R_{s}$ and soil temperature is better than between $R_{s}$ and air temperature (Yang et al. 2017). In arctic, boreal and cold temperate regions, $R_{s}$ is more sensitive to temperature changes and the $Q_{10}$ is higher (Yuste et al. 2010). Several measurements have indicated a $Q_{10}$ of ca. 2.0 for temperate forests, while for the forested lands in northeastern China, ca. 1.3-1.8 in the growing season and 3.0-5.0 in the dormant season (Mills et al. 2011). Traditionally regarded as an important carbon sink, under a warming climate, the abovementioned regions may experience greatly elevated soil respiration and rapid and massive release of $\mathrm{CO}_{2}$ into the atmosphere, positively feeding back to climate warming (Muñoz et al. 2016). However, the estimation of $Q_{10}$ is mostly based on the measurements of $R_{s}$ and other parameters in a specific environment at a given time period (Chen et al. 2020). For example, the weather on days for many measurements has been mostly sunny; however, in some forests, the number of rainy days in a year predominates. Therefore, the data from continuous measurements for entire growing seasons or over many years will more accurately reflect the responses of forest soil respiration to climate changes at seasonal to decadal scales.

Soil respiration occurs in the internal environment of the soil. Current observational methods cannot directly monitor the mechanisms of soil respiration, and thus most widely used methods per se adopt the measurements of water and heat parameters to explain $R_{s}$ changes (Schuur et al. 2015). However, most researchers do not have a commonly agreed depth for the measurements of soil temperature (He et al. 2017). Soil respiration occurs at different soil depths but the transmission of surficial temperature changes to soil depths has a certain time lag and exponentially dampened amplitudes, leading to greatly reduced changes in soil temperature at depth (Padarian et al. 2017). Thus, there are still three key questions remaining unanswered: (1) Are/is there a depth(s) with the highest $R_{s}$ ? (2) Which depth(s) yield(s) the highest $R_{s}$ ? and, (3) Can the correlation between $R_{s}$ and soil temperature at different depths indirectly reveal this/ these depth(s)?

Therefore, with these three unknowns in mind, we chose a Xing' an larch (Larix gmelinii (Rupr.) Kuzen.) forest as the research site (boreal forest ecosystem) in the northern Daxing' an Mountains of Inner Mongolia Autonomous Region, Northeast China. The Daxing' an Mountains are covered by a boreal cold temperate coniferous forest. As an important part of the forest belt in eastern Asia, it plays a key role in carbon uptake and in maintaining ecological balances. We hypothesize that the $Q_{10}$ obtained by highfrequency and continuous observation may better reflect the $R_{s}$ change rate over a certain period of time (including precipitation and other local or short-term hydrological events), and the spatiotemporal variation of $Q_{10}$ may well reflect the influences of ground and air temperature and freeze-thaw processes on the $R_{S}$ in northern coniferous forests. Based on this hypothesis, we observed the soil $\mathrm{CO}_{2}$ fluxes in situ. This study is important for understanding and predicting the 
soil carbon cycle and its changes in the Xing' an larch forest ecosystem in the cold temperate zone, and for regional environmental management.

\section{Materials and methods}

\section{Study area}

This study was conducted in an experimental plot of the National Field Observation and Research Station of the Daxing'an Ecosystems (NFORS-DXE; $121^{\circ} 30^{\prime} 20^{\prime \prime}-121^{\circ} 31^{\prime} 0^{\prime \prime} \mathrm{E}$ and $50^{\circ} 49^{\prime} 40^{\prime \prime}-50^{\circ} 51^{\prime} 35^{\prime \prime} \mathrm{N}$; elevation of 791-845 m a.s.l.) in the Inner Mongolia Autonomous Region (Fig. 1), located $16 \mathrm{~km}$ north of Genhe City in the northern part of Northeast China. The area is characterized by a continental monsoonal climate with extensive presence of frozen ground. The multi-year average (2007-2020) mean annual air temperature was $-2.9^{\circ} \mathrm{C}$. Precipitation $(60 \%)$ fell in summer (generally July and August), and the snowfall generally occurred September to the following May. The multi-year average of mean snow depth was $25 \mathrm{~cm}$ during 2007-2020.

The experimental plot is set in a Xing' an larch forest at an elevation of about $820 \mathrm{~m}$ a.s.l. on a northern slope. Xing' an larch, with an average diameter of breast height (DBH) of $10 \mathrm{~cm}$ and an average height of $10 \mathrm{~m}$ dominates the boreal ecosystem. Species of Ledum palustre L. prevails in the shrub understory with an average height of $0.3 \mathrm{~m}$ and a cover of $39 \%$. The forest is formed over brown coniferous forest soil, with a soil pedon layer $30-40 \mathrm{~cm}$ thick, a 10 -cm humus layer, $1.3 \pm 0.06 \mathrm{~g} \cdot \mathrm{cm}^{-3}$ soil bulk density, and $42.7 \pm 0.9 \mathrm{~g} \cdot \mathrm{kg}^{-1}$ soil organic matter.

\section{Sample settings}

A $20 \mathrm{~m} \times 20 \mathrm{~m}$ representative fixed sample plot was established, and in order to ensure the reliability and representativeness of the measurements, it was divided into sixteen $5 \mathrm{~m} \times 5 \mathrm{~m}$ sub-plots. From these sub-plots, four sub-samples were randomly selected as the observation points for soil respiration. At these points, a $10-\mathrm{cm}$ high PVC soil ring with a 20-cm diameter was pressed into the soil up to $5 \mathrm{~cm}$, and the surface litter was removed. Use of the soil ring can prevent the horizontal diffusion of gas and forms a closed environment to allow for more accurate gas measurements.

\section{Research approach and methods}

A fully automatic, multi-channel, soil flux measurement system was adopted (Fig. 2), consisting of a portable greenhouse gas analyzer (UGGA) (LGR Corporation, San Jose, CA, USA) and a control unit (SF-3000) (Beijing Riga United Technology Co., Ltd., Beijing, China). This instrument performs continuous, multi-channel, high frequency measurement with excellent data continuity. At each subsample site, the gas inside the chamber was measured every three minutes, including a gas balance time of $30 \mathrm{~s}$ and a gas measurement time of $150 \mathrm{~s}$. Four sub-samples were automatically measured at 12-min intervals. This selection of the measurement cycle followed that of other researchers using similar instruments (Verchot et al. 2000; Song et al. 2006; Jahn et al. 2010).

To protect the instrument from damage by extreme weather, the soil greenhouse gas observation system (SF3000 , UGGA) was placed in a steel house next to the sample
Fig. 1 Location of the study area and plot
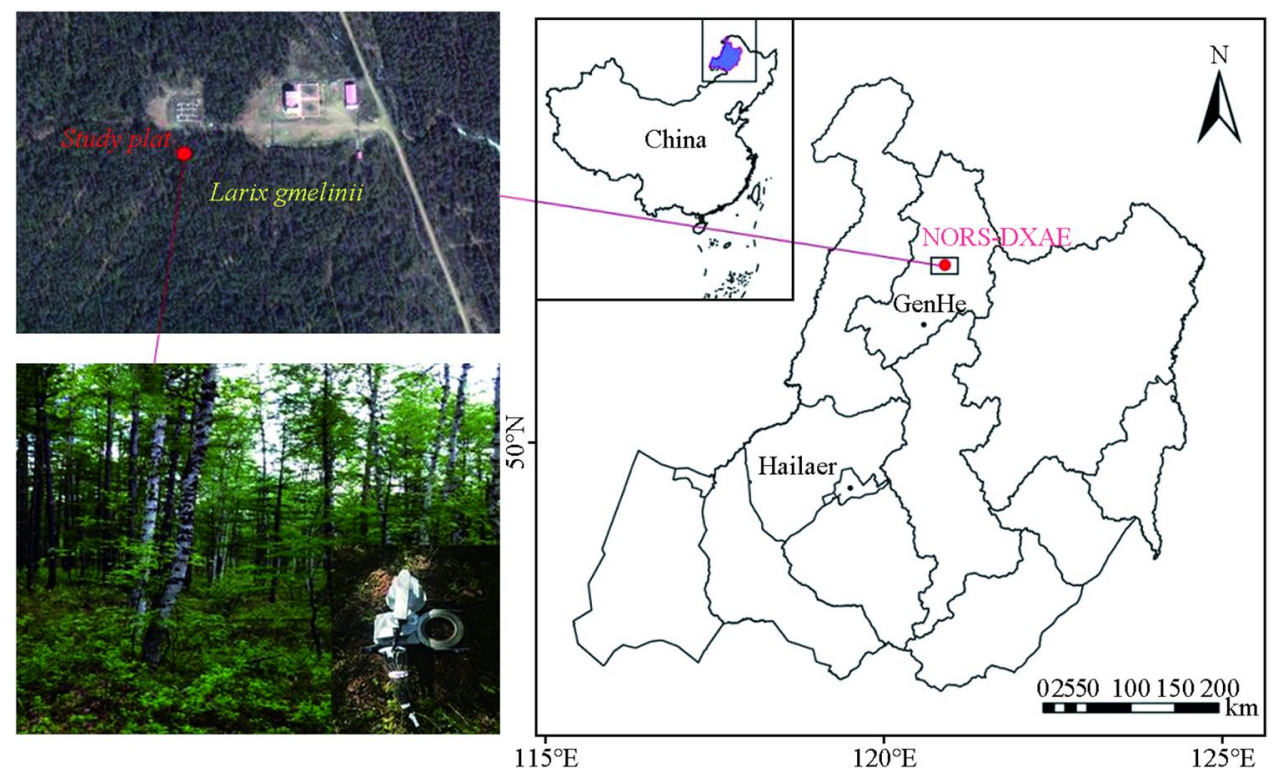
Fig. 2 LGR automatic multichannel soil fluxes measurement system used in this study during the period of 1 April to 30 September, 2019
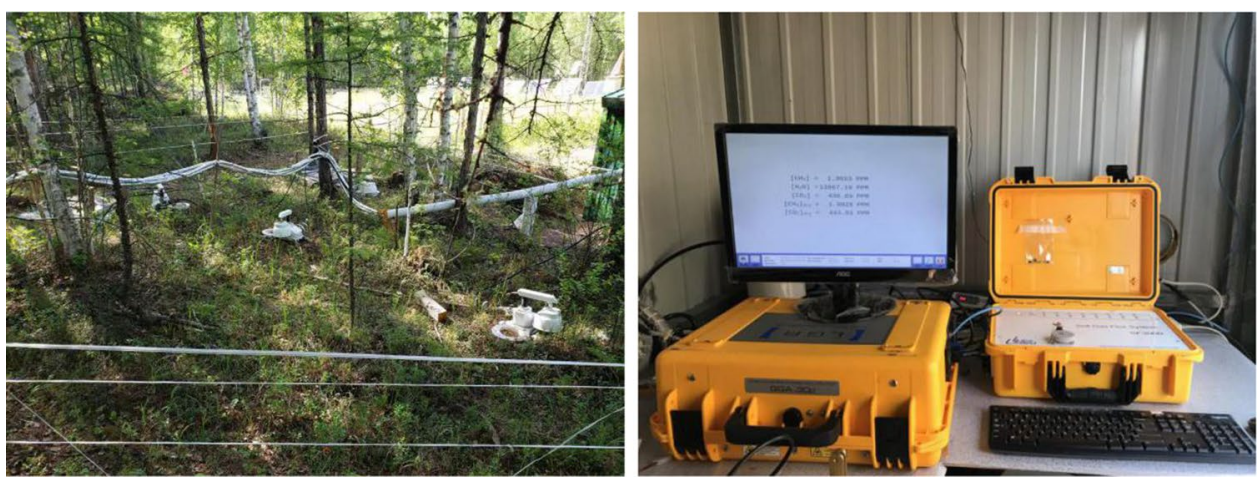

plot (Fig. 2), with reliable batteries under all-weather conditions. Four fully automatic breathing chambers were placed at the soil respiration point of the instrument in order to maximize the number of observations of the natural $R_{\mathrm{s}}$. The instrument and data were checked and maintained daily during the measurement period. The concentration of water vapor and $\mathrm{T}_{0 \mathrm{~cm}}$ inside the breathing chambers were automatically analyzed by the UGGA analyzer, and the $T_{\text {air }}, T_{5 \mathrm{~cm}}$, and $T_{10 \mathrm{~cm}}$ measured simultaneously every hour by the standard weather station $20 \mathrm{~m}$ from the sample plot.

\section{Data processing}

The data obtained from the UGGA analyzer were soil $\mathrm{CO}_{2}$ and water vapor concentrations. In this study, the release rate of gas fluxes from the soil surface to the atmosphere is positive (+), and the absorption rate of gas fluxes from the atmosphere to the soil surface, negative (-). Changes in soil $\mathrm{CO}_{2}$ and water vapor concentrations were converted into gas fluxes using a gas fluctuation model for calculating the closed-loop fluxes (Eq. 1), and the data were screened using the six times standard deviation method (Pumpanen et al. 2004; Arias-Navarro et al. 2017). This step was carried out using the SPSS software, and the results were visualized with the Origin software. The temperature sensitivity of $R_{s}$ $\left(\mathrm{Q}_{10}\right)$ was calculated using Eqs. 2 and 3 (Christiansen et al. 2015).

$$
F_{C}=\frac{10 V P_{0}\left(1-\frac{W_{0}}{1000}\right)}{R S\left(T_{0}+273.15\right)} \times \frac{\partial C^{\prime}}{\partial \mathrm{t}}
$$

where, $F_{c}$ is the measured gas fluxes of the soil surface in $\mathrm{mmol} \cdot \mathrm{m}^{-2} \cdot \mathrm{s}^{-1} ; V$, the total internal volume of the air chamber system in $\mathrm{cm}^{3} ; P_{0}$, the initial air pressure in the air chamber in $\mathrm{kPa} ; W_{0}$, the initial water vapor concentration (WVC) of the air in the air chamber in \%o; $R$, the universal gas constant $8.314 \mathrm{~Pa} \cdot \mathrm{m}^{3} \cdot \mathrm{K}^{-1} \cdot \mathrm{mol}^{-1} ; S$, the soil measurement area in $\mathrm{cm}^{2} ; T_{0}$, the initial air temperature in the air chamber in
${ }^{\circ} \mathrm{C} ; \frac{\partial C^{\prime}}{\partial \mathrm{t}}$, the discharge rate of dry measured gas after water calibration in $\mathrm{mmol}^{-1} \cdot \mathrm{s}^{-1}$;

The $Q_{10}$ calculation formula:

$R_{s}=a e^{b T}$

$Q_{10}=e^{10 b}=e^{10\left(\ln R_{s}-\ln a\right) / T}$

where, $R_{s}$ is the soil respiration rate in $\mu \mathrm{mol} \cdot \mathrm{m}^{-2} \cdot \mathrm{s}^{-1} ; T$ is the soil surface temperature in ${ }^{\circ} \mathrm{C}, a$ and $b$ are the coefficients of the equations. $Q_{10}$ values of each time scale were fitted by exponential function of $\mathrm{CO}_{2}$ fluxes and soil temperature at that time scale and then calculated with the $Q_{10}$ formula.

\section{Results}

\section{Changes in near-surface soil temperatures, water vapor concentration (WVC) and $\boldsymbol{R}_{s}$}

The climate of the Xing'an larch forest at relatively higher latitudes $\left(50^{\circ} 49^{\prime} 40^{\prime \prime}-50^{\circ} 51^{\prime} 35^{\prime \prime} \mathrm{N}\right)$ is characteristic of a cold, long winter but a moist, short summer (growing season from April to September) (Fig. 3). There were larger differences amongst $T_{\text {air }}, T_{0 \mathrm{~cm}}$, and $T_{10 \mathrm{~cm}}$ and from May to August, the $T_{\text {air }}$ was always higher than the surface temperature $\left(T_{0 \mathrm{~cm}}\right)$. The $T_{0 \mathrm{~cm}}$ was close to $0{ }^{\circ} \mathrm{C}$ in mid-and late-April, above $0{ }^{\circ} \mathrm{C}$ during the day and below $0{ }^{\circ} \mathrm{C}$ at night. The average daily temperature in summer increased slowly, and the highest daily average $T_{0 \mathrm{~cm}}$ of $18.7^{\circ} \mathrm{C}$ occurred on $14 \mathrm{July}, 2019$. Afterwards, the $T_{0 \mathrm{~cm}}$ declined steadily. In September, 2019, the daily average $T_{0 \mathrm{~cm}}$ approached $0{ }^{\circ} \mathrm{C}$, and the nighttime surface temperature began to fall below $0{ }^{\circ} \mathrm{C}$.

Because of the thermal insulation of the soil, air temperatures and soil temperatures at the two depths displayed vertical and temporal variations. They largely peaked in July when their differences reached a minimum. In each month, variations in $\mathrm{T}_{10 \mathrm{~cm}}$ were always the smallest among all measured soil temperatures at $T_{0 \mathrm{~cm}}, T_{5 \mathrm{~cm}}$ and $T_{10 \mathrm{~cm}}$. The result of 
Fig. 3 Air $\left(T_{\text {air }}\right)$, soil surface $\left(T_{0 \mathrm{~cm}}\right)$, and shallow soil temperatures at 5 and $10 \mathrm{~cm}\left(T_{5 \mathrm{~cm}}\right.$ and $T_{10 \mathrm{~cm}}$, respectively) in 2019 . The color bars indicate the range of measured values; The small rectangles indicate the average of the measured values; and the extended lines from the small rectangles stand for one standard deviation from average of the measured value

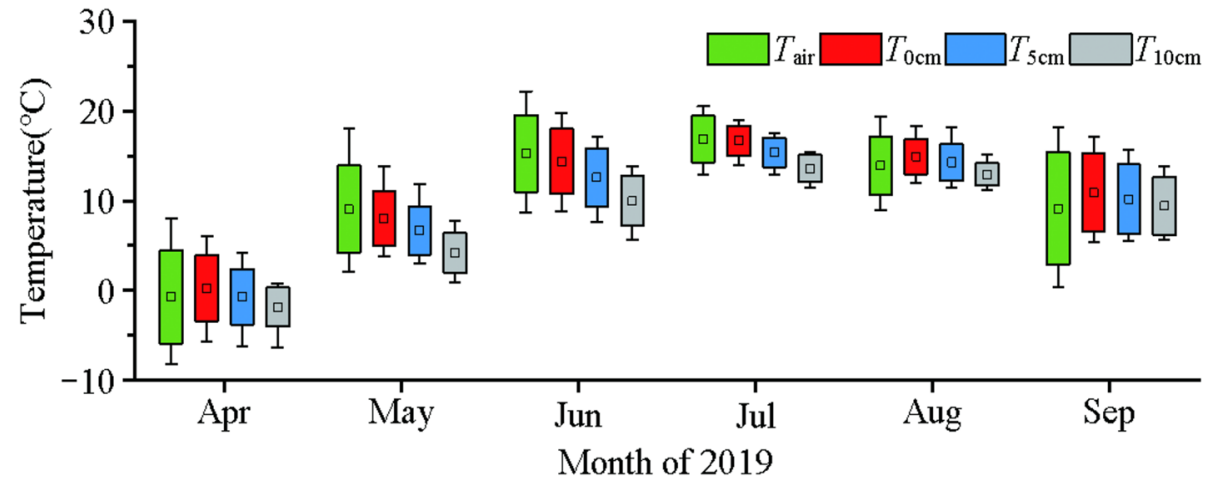

the single factor analysis indicates no significant difference between $T_{\text {air }}$ and $T_{0 \mathrm{~cm}}$ or $T_{5 \mathrm{~cm}}(P>0.05)$, but a significant difference between $T_{0 \mathrm{~cm}}$ and $T_{5 \mathrm{~cm}}(P=0.026<0.05)$ and between $T_{0 \mathrm{~cm}}$ and $T_{10 \mathrm{~cm}}(P=0.021<0.05)$.

Monthly changes in the water vapour concentration (WVC) at the soil respiratory observation points are shown in Fig. 4. In mid-April, the WVC stabilized at 3.4\%o-5.0\%o, but it began to fluctuate significantly at the end of April. The WVC peaked the first time at $10.5 \%$ in May, which extended into June; because of increasing rain, surface WVC enriched substantially. The maximum in summer $(20.8 \%$ ) occurred on 21 July 2019 and began to gradually decrease. In mid-tolate September, it was more stable (6.6\%o-10.3\%o).

The continuous observations of soil respiration during the period of near-surface soil thawing (April to May) revealed a very low $R_{s}$ in April of less than $0.1 \mu \mathrm{mol} \cdot \mathrm{m}^{-2} \cdot \mathrm{s}^{-1}$ (Fig. 4). The $R_{s}$ rapidly increased to $0.3 \pm 0.1 \mu \mathrm{mol} \cdot \mathrm{m}^{-2} \cdot \mathrm{s}^{-1}$ at the end of April, and began to fluctuate sharply. At the beginning of May, it was $0.4 \pm 0.2 \mu \mathrm{mol} \cdot \mathrm{m}^{-2} \cdot \mathrm{s}^{-1}$ and two shortterm plumes in $\mathrm{CO}_{2}$ effluxes occurred in May. The first peak occurred May 17 and the second, May 23.

In this region, the growing season is relatively short (June to September). By calculating the daily $\mathrm{R}_{\mathrm{s}}$ averages in the major growth period (Fig. 4), soil respiration was evidently still inactive in June. The release rate of soil $\mathrm{CO}_{2}$ was relatively stable at $1.3 \pm 0.5 \mu \mathrm{mol} \mathrm{m} \mathrm{m}^{-2} \mathrm{~s}^{-1}$. The $R_{s}$ remained unchanged at the beginning and at the end of June, but after 24 June, it began to increase significantly. In July, the upward trend of $R_{s}$ was enhanced and the monthly mean $R_{s}$ was $2.6 \pm 0.5 \mu \mathrm{mol} \mathrm{m} \mathrm{m}^{-2} \mathrm{~s}^{-1}$. Soil respiration began to weaken slowly in August (monthly average $R_{s}$ at $3.3 \pm 1.0 \mu \mathrm{mol} \mathrm{m} \mathrm{m}^{-2} \mathrm{~s}^{-1}$ ), and declined rapidly in September (monthly average $R_{s}$ at $1.9 \pm 0.6 \mu \mathrm{mol} \mathrm{m} \mathrm{m}^{-2} \mathrm{~s}^{-1}$ ). The $R_{s}$ was larger in July and August but lower before early June and in
Fig. 4 Characteristics of watervapor concentration, air $\left(T_{\text {air }}\right)$, soil surface $\left(T_{0 \mathrm{~cm}}\right)$ and soil temperatures $\left(T_{5 \mathrm{~cm}}\right.$ and $\left.T_{10 \mathrm{~cm}}\right)$ at 5 and $10 \mathrm{~cm}$ depths and soil $\mathrm{CO}_{2}$ fluxes during the period of 1 April to 30 September, 2019. a Diurnal variation in water vapor concentration; b Diurnal changes in air temperature and temperatures of soil at different depths; and $\mathbf{c}$ Changes in the diurnal soil $\mathrm{CO}_{2}$ fluxes

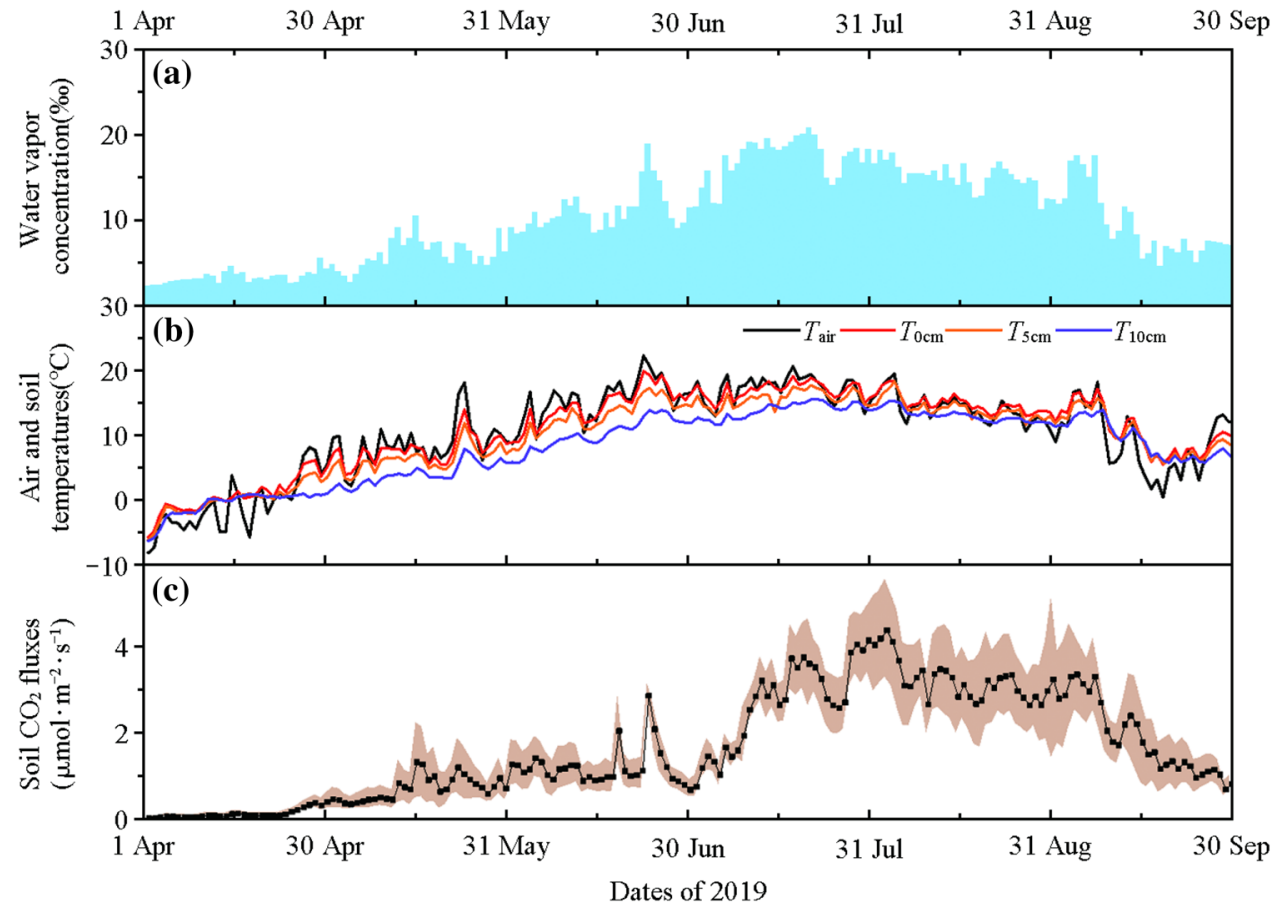


late September. The regional $R_{s}$ also had unique monthly features. For example, the $R_{s}$ was low and stable in June, while it peaked over a short period from the end of July to the beginning of August. This phenomenon may be closely related to the dynamic changes in surface temperatures $\left(T_{0 \mathrm{~cm}}\right)$.

\section{Correlations among $\boldsymbol{R}_{s}$, WVC, and near-surface soil temperatures $\left(T_{0 \mathrm{~cm}}, T_{5 \mathrm{~cm}}\right.$ and $\left.T_{10 \mathrm{~cm}}\right)$}

The functional relationships between $R_{s}$ and environmental variables (WVC, $T_{\text {air }}, T_{0 \mathrm{~cm}}, T_{5 \mathrm{~cm}}$, and $T_{10 \mathrm{~cm}}$ ) were established through regressions. The correlation between the WVC and soil $\mathrm{CO}_{2}$ fluxes is shown in Fig. 5. The $R_{\mathrm{s}}$ was positively correlated with the growing season WVC in 2019. The optimized function of $R_{s}$ is a linear function $\left(R_{s}=0.0002 \mathrm{WVC}-0.4953\right)$ at a significant level $\left(R^{2}=0.79\right.$, $P<0.01)$. There was also a significant exponential correlation between $R_{s}$ and soil temperatures at different depths (Fig. 6). When $T_{0 \mathrm{~cm}}$ started to drop below $0{ }^{\circ} \mathrm{C}$, the $R_{s}$ continued to zero. The lowest correlation was found between the $R_{s}$ and $T_{\text {air }}$, with the best fitting at a significant level $\left(R_{S}=0.1880 e^{0.1562 \text { Tair }}, R^{2}=0.67\right.$, and $\left.P<0.01\right)$. With increasing depth, the correlation between $R_{s}$ and soil temperature gradually improved, with the highest correlation $\left(R_{s}=0.1624 e^{0.2190710 c m}, R^{2}=0.83\right.$, and $\left.P<0.01\right)$ found at a depth of $10 \mathrm{~cm}$. These significant correlations indicate the important influences of near-surface soil temperatures on the temporal variability of $R_{s}$ in the growing season.

There was a close relationship between seasonal changes in $R_{s}$ and dynamically changing soil temperatures, but to what degree monthly $R_{s}$ is controlled by soil temperature needs further investigation. In each month, an exponential

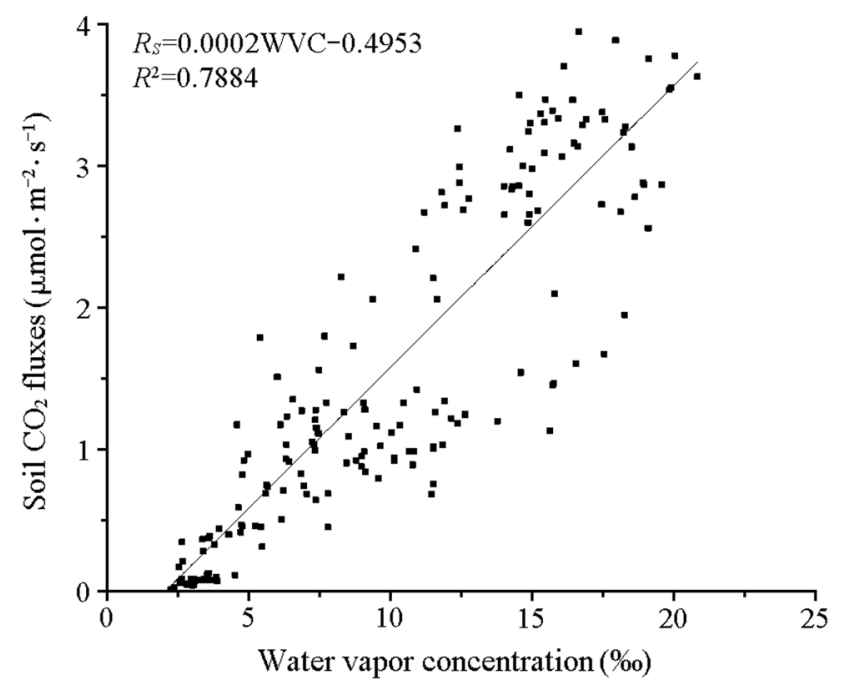

Fig. 5 Correlation analysis of soil respiration and water vapor concentration (WVC) during April-September 2019 function was established for relating $R_{s}$ and near-surface soil temperatures from April to September (Table 1). The correlation coefficient decreased significantly from May to August. In particular, in the rainy months of June and July, $R_{S}$ and soil temperatures were poorly correlated, whereas in April and September, the correlation was better. Thus, shortterm $R_{s}$ changes may be affected by a variety of factors (e.g., a continuous 3-day pulse of $R_{s}$ in June; an $R_{s}$ decrease in late July), and the impacts from a single factor of near-surface soil temperatures only provides a limited explanation for this observation.

In this study, $Q_{10}$ was calculated for evaluating the sensitivity of soil respiration to near-surface soil temperatures at different depths each month using Eq. 2 (Table 2). Soil $\mathrm{CO}_{2}$ effluxes were generally sensitive to temperature changes, although the effects were slight in the early stages of near-surface soil thawing. The $Q_{10}$ to $T_{0 \mathrm{~cm}}$ was 11.5 during this period; however, that of $T_{10 \mathrm{~cm}}$ was as high as 36.6. At the beginning of April, soil $\mathrm{CO}_{2}$ fluxes were small $\left(<0.1 \mu \mathrm{mol} \cdot \mathrm{m}^{-2} \mathrm{~s}^{-1}\right)$, but by the end of the month, the $R_{s}$ began to gradually recover and rose to $0.3 \mu \mathrm{mol} \cdot \mathrm{m}^{-2} \mathrm{~s}^{-1}$. Although $\mathrm{CO}_{2}$ fluxes in April were low, its rate of increase was significantly higher than that in other months, leading to high April $Q_{10}$ values. $Q_{10}$ was lower and stable in the main months of the growing season (June, July, and September). $\mathrm{CO}_{2}$ fluxes were the most sensitive to July temperatures because their increasing rate was the most rapid at relatively high, stable soil temperatures. With increasing soil depth, the amplitudes of changes in temperatures decreased exponentially, enlarging the $Q_{10}$. Throughout the study period, the $Q_{10}$ for soil $\mathrm{CO}_{2}$ fluxes to the $T_{0 \mathrm{~cm}}, T_{5 \mathrm{~cm}}$, and $T_{10 \mathrm{~cm}}$ were 5.6, 6.3, and 7.2, respectively.

In different months of the major growing season, changes in soil temperature were relatively small but the $Q_{10}$ fluctuated more markedly, indicating that $Q_{10}$ is determined by changes in the $R_{s}$ and temperature over a specific period of time. It would also be affected by other factors, for example, the monthly average $Q_{10}$ in July 2019 was significantly higher than in June and August, and it might be difficult to explain the higher $Q_{10}$ values only from the perspective of soil temperature. From the WVC variation characteristics in Fig. 3, the WVC in July was highest in the growing season, indicating an important contribution of frequent rainfall and the resultant high surface WVC to the high $Q_{10}$.

In order to find the daily variations in $Q_{10}$, a sunny day was selected in the middle of April to September (Table 3). The daily range of soil surface temperatures on April 15 was $24.0{ }^{\circ} \mathrm{C}$, and the ratio of maximum to minimum soil $\mathrm{CO}_{2}$ fluxes was 3.2; on May 19 it was $18.4^{\circ} \mathrm{C}$, and the ratio was 2.1. Daily $Q_{10}$ were 1.9 and 1.8 in April and May, respectively, significantly higher than the monthly average (1.3) from June to September. 

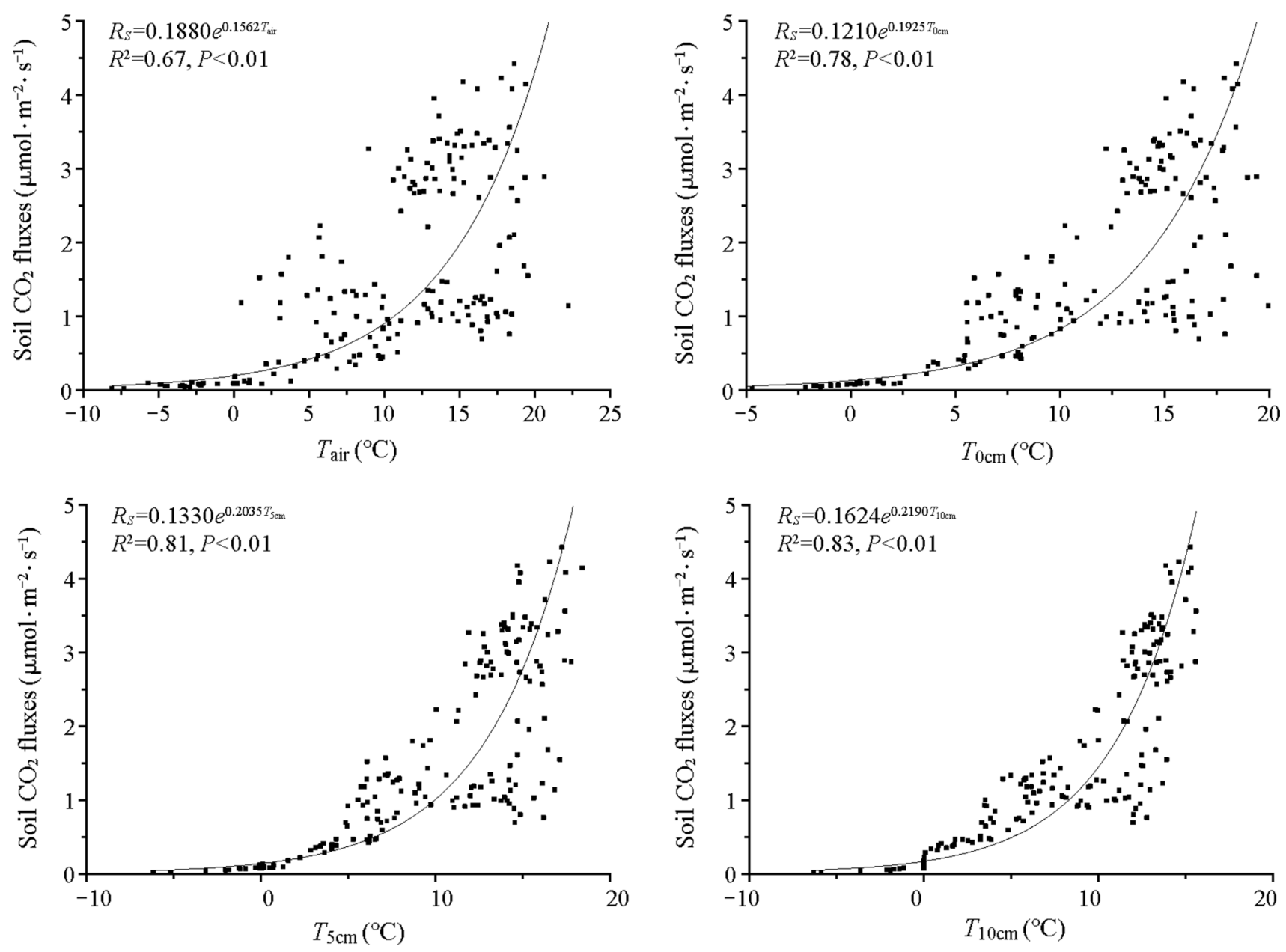

Fig. 6 Correlation between soil respiration rate $\left(R_{s}\right)$ and air $\left(T_{\text {air }}\right)$, soil surface $\left(T_{0 \mathrm{~cm}}\right)$ and near-surface soil $\left(T_{5 \mathrm{~cm}}\right.$ and $\left.T_{10 \mathrm{~cm}}\right)$ temperatures

\section{Discussion}

\section{Spatiotemporal variations of $Q_{10}$}

$Q_{10}$ values show distinct temporal variability. At different time scales, the controlling or influencing factors for ecosystem respiration rates and $Q_{10}$ may vary remarkably (Maienza et al. 2017; Wang and Wang 2017). Soil respiration is variable during the main portions of the growing season and during soil thawing. There was a significantly low variability in soil $\mathrm{CO}_{2}$ fluxes in spring and autumn and high variability in summer. Soil respiration rates $\left(R_{s}\right)$ also exhibit monthly variations such as low, stable values in June and a short peak period in late July to early August.

As $Q_{10}$ is controlled by different ecological processes and mechanisms, the values display complex interannual, seasonal and daily variabilities (Song et al. 2016). In this study, the daily average $Q_{10}$ in the growing season of 2019 was $1.5 \pm 0.2$ for the larch forest soil at a relatively high latitude of about $50^{\circ} \mathrm{N}$. $Q_{10}$ was between 1 and 2 approximately, and the range in variation of $Q_{10}$ would be very large when calculated at longer time scales, such as at a month and major growing period. For example, the $\mathrm{Q}_{10}$ at the 10-cm depth in July reached 42.0. The daily $Q_{10}$ was smaller than the monthly $Q_{10}$ for the same site and time because of the exclusion of the influences of climate variations, such as rain, and; this better reflected the intrinsic temperature sensitivity of soil respiration (Tarkhov et al. 2019). At a seasonal scale, $Q_{10}$ values not only indicate the immediate controlling effect of temperature on soil enzyme activities, but also long-term phenological control of changes in microbial communities and root growth dynamics (Gromova et al. 2020). Because of the differences between long-term and short-term temperature sensitivities of soil respiration, attention must be given to scaling issues when calculating or using $Q_{10}$ values for estimating carbon budgets.

$Q_{10}$ data for total global soil respiration range from 1.3 to 3.3 , with a median of 2.4, most of which are forests (Yuste et al. 2010; Aguilos et al. 2018). $Q_{10}$ values are closely related to latitude (Doetterl et al. 2015), and in addition, for 


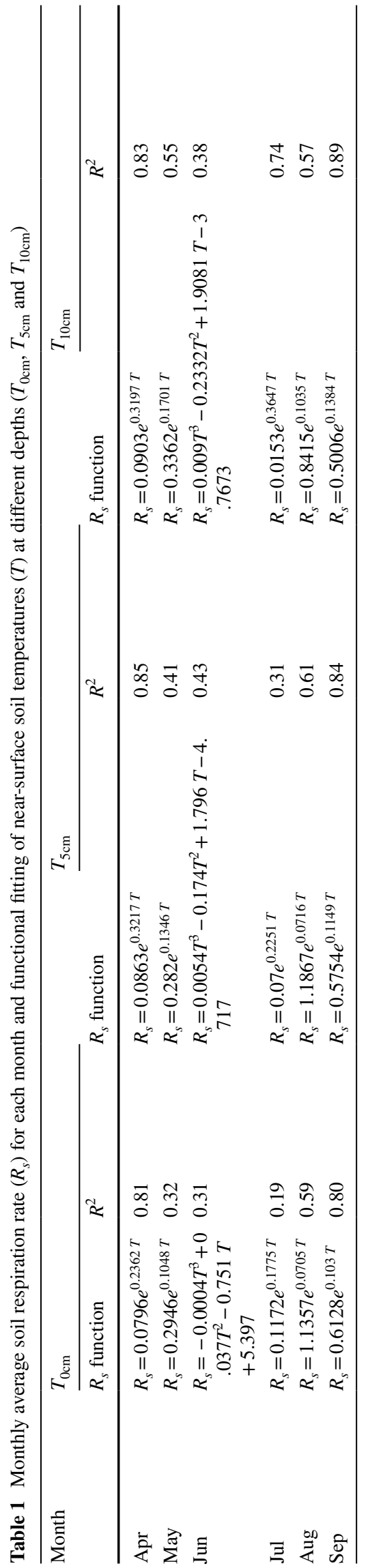

forest ecosystems, they are lower at low and mid-latitudes, while higher at high latitudes, such as 3.4-5.6 for the U.S. Harvard Forest ecosystem at latitude around $42^{\circ} \mathrm{N}$ the 4.2 of the Danish beech forest at $56^{\circ} \mathrm{N}$ (Janssens and Pilegaard 2003). Therefore, because of the relatively higher latitude at Genhe, Northeast China, the $Q_{10}$ values of the boreal larch forest soil obtained in this study are significantly higher than that of the global average.

\section{Effects of different factors on soil respiration and $Q_{10}$ values}

In this study, higher $Q_{10}$ values were found in the cold season. This is consistent with the results of the inter-monthly variations of $Q_{10}$ in alternating periods of low and high temperatures from a study in north China (Wang et al. 2010). Through regression analysis of monthly soil $\mathrm{CO}_{2}$ and temperature, it was recognized that a single soil temperature factor cannot fully explain short-term changes in soil $\mathrm{CO}_{2}$ fluxes, such as the large three-day pulse in June (Fig. 3). $Q_{10}$ values could also be indirectly affected by the frequency and intervals of soil respiration measurements (Chen et al. 2020). In a measurement process without a specific period (freeze thaw period, rainy season) and long measurement intervals, the calculated $Q_{10}$ values tend to be lower (Peichl et al. 2014; Hu et al. 2016). At the same time, the observed $Q_{10}$ values are also affected by soil depth ( $\mathrm{Li}$ et al. 2020). In this study, the $Q_{10}$ values were significantly higher than those of the surface mainly because the changes in temperature in deeper soils have a dampening effect compared with the surface soil, and can better reflect the real temperatures of the internal soil environment. Therefore, changes in soil respiration rates are affected by a variety of factors, but it remains unclear how many factors affect soil respiration in a coordinated way.

\section{Conclusion}

There are seasonal variations in soil respiration and soil temperature is the dominant factor, with rainfall-induced changes in water vapour concentration the main factor for short-term fluctuations in soil $\mathrm{CO}_{2}$ fluxes. $Q_{10}$ differs with time scales and soil depth, values for the surface thawing period are significantly higher than those for the growing season or thawed period of surface soil. Furthermore, soil respiration rates in the early stage of near-surface soil thawing and in the middle of the main growing period are more sensitive to temperature changes. The difference in the impacts of $Q_{10}$ by soil temperatures at various depths is manifested by the higher $Q_{10}$ values of temperatures of the deep soil than those of the shallow soil. Daily $Q_{10}$ values are significantly lower than monthly and seasonal 
Table 2 Sensitivity $\left(Q_{10}\right)$ of soil respiration to soil temperatures at different depths for each month of the growing season in 2019

\begin{tabular}{lccc}
\hline Month/period & $Q_{10}\left(T_{0 \mathrm{~cm}}\right)$ & $Q_{10}\left(T_{5 \mathrm{~cm}}\right)$ & $Q_{10}\left(T_{10 \mathrm{~cm}}\right)$ \\
\hline Apr & 10.0 & 22.1 & 24.5 \\
May & 2.8 & 3.8 & 5.5 \\
Average over the thawing period of near-surface soil & 11.5 & 16.4 & 36.6 \\
Jun & 1.4 & 1.5 & 1.5 \\
Jul & 6.5 & 10.5 & 42.0 \\
Aug & 2.1 & 2.1 & 3.0 \\
Sept & 3.1 & 3.5 & 4.5 \\
Average over the major growth periods (four months average) & 1.8 & 2.3 & 3.8 \\
Average over all the observation period (April to Sept) & 5.6 & 6.3 & 7.2 \\
\hline
\end{tabular}

(1) Average $Q_{10}$ over the thawing period (April and May) of near-surface soil was derived by the exponential function and $\mathrm{Q}_{10}$ function; (2) Average $Q_{10}$ over the major growing period (June, July, August and September) was derived by the exponential function and $Q_{10}$ function; and (3) Average $Q_{10}$ over the all the study period (April to September) was derived by the exponential function and $Q_{10}$ function.

Table $3 Q_{10}$ values on sunny days in the middle of each month of the growing season

\begin{tabular}{|c|c|c|c|c|c|c|}
\hline Date & $\begin{array}{l}\text { Maximum surface } \\
\text { temperature }\left({ }^{\circ} \mathrm{C}\right)\end{array}$ & $\begin{array}{l}\text { Minimum surface } \\
\text { temperature }\left({ }^{\circ} \mathrm{C}\right)\end{array}$ & $\begin{array}{l}\text { Mean surface tem- } \\
\text { perature }\left({ }^{\circ} \mathrm{C}\right)\end{array}$ & $\begin{array}{l}\text { Maximum } \mathrm{CO}_{2} \text { fluxes } \\
\left(\mu \mathrm{mol} \mathrm{m} \mathrm{m}^{-1}\right)\end{array}$ & $\begin{array}{l}\text { Minimum } \mathrm{CO}_{2} \text { fluxes } \\
\left(\mu \mathrm{mol} \mathrm{m} \mathrm{s}^{-1}\right)\end{array}$ & $Q_{10}$ \\
\hline $15 \mathrm{Apr}$ & 12.2 & -11.7 & 0.9 & 0.16 & 0.05 & 1.89 \\
\hline 19 May & 20.6 & 2.2 & 6.7 & 2.09 & 1.01 & 1.76 \\
\hline 17 Jun & 12.3 & -2.6 & 11.5 & 1.74 & 1.09 & 1.51 \\
\hline $15 \mathrm{Jul}$ & 30.0 & 11.5 & 18.8 & 4.12 & 2.36 & 1.35 \\
\hline 13 Aug & 23.2 & 11.9 & 16.1 & 5.01 & 3.66 & 1.25 \\
\hline $12 \mathrm{Sep}$ & 11.7 & -13.9 & 3.7 & 3.62 & 2.11 & 1.21 \\
\hline
\end{tabular}

ones; monthly and seasonal values better reflect the changes of soil respiration affected by phenology in the natural state. To improve the accuracy of $Q_{10}$ estimates for simulating soil carbon source and sink in this area, a better understanding of temporal variation characteristics of $Q_{10}$ is needed. Soil moisture is also a key influencing factor for influencing the temperature sensitivity of soil respiration. However, due to a lack of accurate rainfall and soil moisture data, it is difficult to adequately explain the impact of rainfall and soil moisture changes on $Q_{10}$. For future studies, the monitoring of key hydroclimatic and environmental factors in the long-term monitoring of soil respiration rate and greenhouse gases emissions would be strengthened.

Acknowledgements We thank the on-site and logistic support and meteorological data from the Daxing' an Forest Ecosystems Research Station, Genhe, Inner Mongolia, China.

Open Access This article is licensed under a Creative Commons Attribution 4.0 International License, which permits use, sharing, adaptation, distribution and reproduction in any medium or format, as long as you give appropriate credit to the original author(s) and the source, provide a link to the Creative Commons licence, and indicate if changes were made. The images or other third party material in this article are included in the article's Creative Commons licence, unless indicated otherwise in a credit line to the material. If material is not included in the article's Creative Commons licence and your intended use is not permitted by statutory regulation or exceeds the permitted use, you will need to obtain permission directly from the copyright holder. To view a copy of this licence, visit http://creativecommons.org/licenses/by/4.0/.

\section{References}

Aguilos M, Hérault B, Burban B, Wagner F, Bonal D (2018) What drives long-term variations in carbon flux and balance in a tropical rainforest in French Guiana? Agric For Meteorol 253-254:114-123

Arias-Navarro C, Díaz-Pinés E, Klatt S, Brandt P, Rufino MC, Butterbach-Bahl K, Verchot L (2017) Spatial variability of soil $\mathrm{N}_{2} \mathrm{O}$ and $\mathrm{CO}_{2}$ fluxes in different topographic positions in a tropical montane forest in Kenya. J Geophys Res Biogeosci 122(3):514-527

Chen H, Tian HQ (2005) Does a general temperature-dependent $\mathrm{Q}_{10}$ model of soil respiration exist at biome and global scale? $\mathrm{J}$ Integr Plant Biol 47(11):1288-1302

Chen ST, Wang J, Zhang TT, Hu ZH (2020) Climatic, soil, and vegetation controls of the temperature sensitivity $\left(Q_{10}\right)$ of soil respiration across terrestrial biomes. Glob Ecol Conserv. https:// doi.org/10.1016/j.gecco.2020.e00955 
Christiansen JR, Outhwaite J, Smukler SM (2015) Comparison of $\mathrm{CO}_{2}, \mathrm{CH}_{4}$ and $\mathrm{N}_{2} \mathrm{O}$ soil-atmosphere exchange measured in static chambers with cavity ring-down spectroscopy and gas chromatography. Agric For Meteorol 211:48-57

Doetterl S, Stevens A, Six J, Merckx R, Van Oost K, CasanovaPinto M, Casanova-Katny A, Muñoz C, Boudin M, Zagal E (2015) Soil carbon storage controlled by interactions between geochemistry and climate. Nat Geosci 8:780-783

Gromova MS, Matvienko AI, Makarov MI, Cheng CH, Menyailo OV (2020) Temperature sensitivity $\left(Q_{10}\right)$ of soil basal respiration as a function of available carbon substrate, temperature, and moisture. Eurasian Soil Sci 53(3):376-381

He Y, Zhou X, Jiang L, Li M, Du Z, Zhou G, Shao J, Wang X, Xu Z, Bai SH (2017) Effects of biochar application on soil greenhouse gas fluxes: a meta-analysis. GCB Bioenergy 9(4):743-755

Hu HQ, Hu TX, Sun L (2016) Spatial heterogeneity of soil respiration in a Larix gmelinii forest and the response to prescribed fire in the Greater Xing' an Mountains. China J For Res 27(5):1153-1162

Jahn M, Sachs T, Mansfeldt T (2010) Global climate change and its impact on the terrestrial Arctic carbon cycle with special regards to ecosystem components and the greenhouse-gas balance. J Plant Nutr Soil Sci 173(5):627-643

Janssens IA, Pilegaard K (2003) Large seasonal changes in $\mathrm{Q}_{10}$ of soil respiration in a beech forest. Glob Change Biol 9(9):911-918

Li J, Pendall E, Dijkstra FA, Nie M (2020) Root effects on the temperature sensitivity of soil respiration depend on climatic condition and ecosystem type. Soil Tillage Res 199:104574. https://doi.org/ 10.1016/j.still.2020.104574

Liu P, Zha T, Jia X, Bourque PA, Muhammad H (2020) Soil respiration sensitivity to temperature in biocrusted soils in a desert-shrubland ecosystem. Catena 191:104556

Mahecha MD, Markus Reichstein M, Carvalhais N (2010) Global convergence in the temperature sensitivity of respiration at ecosystem level. Science 329:838-840

Maienza A, Genesio L, Acciai M, Miglietta F, Pusceddu E, Vaccari FP (2017) Impact of biochar formulation on the release of particulate matter and on short-term agronomic performance. Sustainability 9:1131

Mills R, Glanville H, McGovern S, Emmett B, Jones DL (2011) Soil respiration across three contrasting ecosystem types: comparison of two portable IRGA systems. J Plant Nutr Soil Sci 174:532-535

Muñoz C, Cruz B, Rojo F, Campos J, Casanova M, Doetterl S, Boeckx P, Zagal E (2016) Temperature sensitivity of carbon decomposition in soil aggregates along a climatic gradient. J Soil Sci Plant Nutr 16:461-476

Padarian J, Minasny B, Mcbratney AB (2017) Chile and the Chilean soil grid: a contribution to GlobalSoilMap. Geoderma Reg 9:17-28

Paustian K, Lehmann J, Ogle S, Reay D, Robertson GP, Smith P (2016) Climate-smart soils. Nature 532:49-57

Peichl M, Arain A, Moore T, Brodeur J, Khomik M, Ullah S, RestrepoCoupé N, McLaren J, Pejam M (2014) Carbon and greenhouse gas balances in an age sequence of temperate pine plantations. Biogeosci Discussions 11:8227-8257

Pokharel P, Kwak JH, Ok YS, Chang SX (2018) Pine sawdust biochar reduces GHG emission by decreasing microbial and enzyme activities in forest and grassland soils in a laboratory experiment. Sci Total Environ 625:1247-1256

Powlson DS, Whitmore AP, Goulding KW (2011) Soil carbon sequestration to mitigate climate change: a critical re-examination to identify the true and the false. Eur J Soil Sci 62(1):42-55
Pumpanen J, Kolari P, Ilvesniemi H, Minkkinen K, Vesala T, Niinistö S, Lohila A, Larmola T, Morero M, Pihlatie M (2004) Comparison of different chamber techniques for measuring soil $\mathrm{CO}_{2}$ effluxes. Agric For Meteorol 123:159-176

Qi Y, Liu X, Dong Y, Peng Q, He Y, Sun L, Jia J, Cao C (2014) Differential responses of short-term soil respiration dynamics to the experimental addition of nitrogen and water in the temperate semi-arid steppe of Inner Mongolia, China. J Environ Sci China 26:834-845

Qin L, Lv GH, He XM, Yang JJ, Wang HL, Zhang XN, Ma HY (2015) Winter soil $\mathrm{CO}_{2}$ efflux and its contribution to annual soil respiration in different ecosystems of Ebinur Lake Area. Eurasian Soil Sci 48(8):871-880

Raich JW, Tufekcioglu A (2000) Vegetation and soil respiration: correlations and controls. Biogeochemistry 48:71-90

Schindlbacher A, Jandl R, Schindlbacher S (2014) Natural variations in snow cover do not affect the annual soil $\mathrm{CO}_{2}$ efflux from a mid-elevation temperate forest. Glob Change Biol 20(2):622-632

Schlesinger WH, Andrews JA (2000) Soil respiration and the global carbon cycle. Biogeochemistry 48:7-20

Schuur EAG, Mcguire AD, Schädel C (2015) Climate change and the permafrost carbon feedback. Nature 520(7546):171-179

Song C, Wang Y, Wang Y (2006) Emission of $\mathrm{CO}_{2}, \mathrm{CH}_{4}$ and $\mathrm{N}_{2} \mathrm{O}$ from freshwater marsh during freeze-thaw period in Northeast of China. Atmos Environ 40(35):6879-6885

Song X, Pan G, Zhang C, Zhang L, Wang H (2016) Effects of biochar application on fluxes of three biogenic greenhouse gases: a metaanalysis. Ecosyst Health Sustainability 2(2):e01202. https://doi. org/10.1002/ehs2.1202

Tarkhov MO, Matyshak GV, Ryzhova IM, Goncharova OY, Petrzhik NM (2019) Temperature sensitivity of soil respiration in palsa peatlands of the north of Western Siberia. Eurasian Soil Sci 52(8):945-953

Verchot LV, Davidson EA, Cattânio JH, Ackerman IL (2000) Land-use change and biogeochemical controls of methane fluxes in soils of eastern Amazonia. Ecosystems 3:41-56

Wang SJ, Wang H (2017) Response of soil respiration to a severe drought in Chinese Eucalyptus plantations. J For Res 28(4):841-847

Wang W, Peng S, Wang T (2010) Winter soil $\mathrm{CO}_{2}$ effluxes and its contribution to annual soil respiration in different ecosystems of a forest-steppe ecotone, North China. Soil Biol Biochem 42(3):451-458

Yan T, Song H, Wang Z, Teramoto M, Peng S (2019) Temperature sensitivity of soil respiration across multiple time scales in a temperate plantation forest. Sci Total Environ 688:479-485

Yang X, Meng J, Lan Y, Chen W, Yang T, Yuan J, Liu S, Han J (2017) Effects of maize stover and its biochar on soil $\mathrm{CO}_{2}$ emissions and labile organic carbon fractions in Northeast China. Agr Ecosyst Environ 240:24-31

Yuste JC, Janssens IA, Carrara A, Ceulemans R (2010) Annual $Q_{10}$ of soil respiration reflects plant phenological patterns as well as temperature sensitivity. Glob Change Biol 10(2):161-169

Zhou T, Shi P, Hui D, Luo Y (2015) Global pattern of temperature sensitivity of soil heterotrophic respiration $\left(Q_{10}\right)$ and its implications for carbon-climate feedback. J Geophys Res Biogeosci 114(G2):271-274

Publisher's Note Springer Nature remains neutral with regard to jurisdictional claims in published maps and institutional affiliations. 